\title{
Аналіз експлуатації пневматичних шин в зоні бойових дій
}

\section{Олександр Почечун ${ }^{\mathrm{A}}$; Микола Дорофєєв ${ }^{\mathrm{B}}$; Роман Фомін ${ }^{\mathrm{C}}$}

Received: January 2, 2020 | Revised: February 5, 2020 | Accepted: February 29, 2020

DOI: $10.33445 /$ sds.2020.10.1.10

\begin{abstract}
Анотація
В даній статті проведений аналіз експлуатації пневматичних шин у складі зразків бойових колісних машин та військової автомобільної техніки, які залучені до проведення операції на сході країни. Вказані основні проблеми та надані пропозиції щодо їх вирішення.
\end{abstract}

Ключові слова: пневматична шина, бойова колісна машина, військова автомобільна техніка.

\section{Постановка проблеми}

На теперішній час у Збройних Силах України питання щодо забезпечення бойових колісних машин (БКМ) та військової автомобільної техніки (ВАТ) пневматичними шинами залишається до кінця не вирішеним. Відсутність в Україні власного виробництва пневматичних шин великої вантажопідіймальності (понад 2500 кг), у т. 4. регульованого тиску, змушує експлуатувати пневматичні шини іноземного виробництва (Республіка Білорусь, КНР, РФ). Багато з них, відноситься до, так званого "бюджетного» сегменту 3 посередньою якістю та низькою зносостійкістю (особливо виробництва КНР) та постачається посередниками без належної технічної документації. Як наслідок, вказані пневматичні шини під час інтенсивної експлуатації зношуються та підлягають списанню значно раніше встановлених норм напрацювання.

В основу даної статті покладені матеріали практичної роботи з вивчення досвіду експлуатації пневматичних шин у складі зразків БКМ та ВАТ в районі проведення операції на сході країни.

\section{Постановка завдання}

Mema cmammi. Метою даної статті $\epsilon$ розробка системи поглядів на підвищення ефективності бойових колісних машин (БКМ) та військової автомобільної техніки (ВАТ) із застосуванням сучасних розробок в області науки та відповідного технічного рівня, що буде корисним при розробленні тактикотехнічних вимог до сучасних та перспективних систем озброєння. Актуальність даного питання для Збройних Сил України останнім часом значно зросла, враховуючи ведення бойових дій.

\footnotetext{
А Центральний науково-дослідний інститут озброєння та військової техніки Збройних Сил України, проспект Повітрофлотський, 28, м. Київ, 03049, Україна, старший науковий співробітник, e-mail: gjxtxey1974@gmail.com, ORCID: 00000002-0749-3317

в Центральний науково-дослідний інститут озброєння та військової техніки Збройних Сил України, проспект Повітрофлотський, 28, м. Київ, 03049, Україна, ад’юнкт, e-mail: dorofeev83@meta.ua, ORCID: 0000-0001-8607-2483

с Центральний науково-дослідний інститут озброєння та військової техніки Збройних Сил України, проспект Повітрофлотський, 28, м. Київ, 03049, Україна, старший науковий співробітник, e-mail: roman7803@ukr.net, ORCID: 0000-00016129-0142
} 


\section{Виклад основного матеріалу}

Аналіз досвіду експлуатації пневматичних шин.

1. Шина 12,00R20 моделі КИ-113 HC10, регульованого тиску, 3 протектором підвищеної прохідності, виробництва ПрАТ «Росава», Україна. Індекс навантаження - 140 (до 2500 кг), індекс швидкості - К (до 110 км/год). Тиск повітря при максимальному 5,1 кг/см2, мінімально допустимий - 1,5 $\mathrm{Kr} / \mathrm{CM} 2[1]$.

За досвідом експлуатації пневматичної шини 12,00R20 моделі КИ-113 HC10 у складі бронетранспортера БТР-4Е та його модифікацій показує, що головною проблемою $€$ значне перевантаження шини. Так, загальна вантажопідіймальність 8-ми шин становить 20000 кг, а повна маса бронетранспортера БТР-4Е складає більше 24000 кг. Такі навантаження призводять до погіршення прохідності, керованості, гальмівних властивостей передчасного зносу та руйнування шин (мал. 1), особливо при русі зі зниженим тиском повітря.

В зв'язку з чим, ПрАТ «Росава» знімає гарантійні зобов'язання з шини 12,00R20 моделі КИ-113 НС10, у випадку їі експлуатації у складі бронетранспортера БТР-4Е та його модифікацій (мал.1).

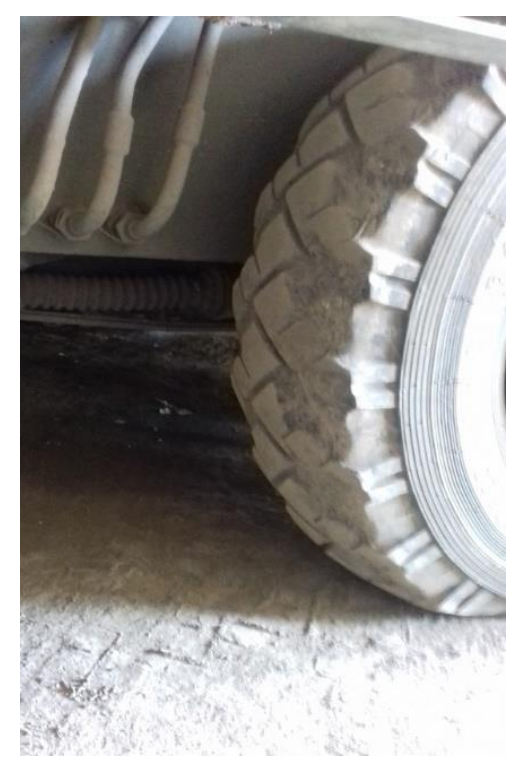

Мал. 1. - Руйнування протектора шини 12,00R20 моделі КИ-113 НС10

Крім того, у зв'язку з негерметичністю шинних кранів, під час стоянки бронетранспортера БТР-4Е, тиск повітря в шинах значно знижується, що в свою чергу пришвидшує процес руйнування каркасу бокової частини шини.

Пневматична шина 12,00R20 моделі КИ113 НС10 встановлюється на бронетранспортери БТР-60,70,80 та броньовану розвідувально-дозорну машину БРДМ-2 замість шин 13.00-18 К-58 та 13.00-18 КИ-80 (із заміною обода). Пневматична шина 12,00R20 моделі КИ-113 НС8 [2] встановлюється на автомобіль ЗиЛ-131 та його модифікації замість шини 12.00-20 М-93. Вказані шини під час експлуатації зарекомендували себе з позитивної сторони, їх ресурс відповідає заявленим ПрАТ «Росава» гарантійним зобов' язанням (35 тис. KM).

Пневматична шина 12,00R20 моделі КИ113 HC10 проходить підконтрольну експлуатацію у складі колеса бронеавтомобіля «Saxon». На теперішній час шини встановлені на чотирьох бронеавтомобілях та мають напрацювання близько 1000 км. 
За відгуками особового складу, шини 12,00R20 моделі КИ-113 НС10 у складі колеса бронеавтомобіля "Saxon» мають показники прохідності, керованості, гальмівних властивостей та стійкості до механічних ушкоджень, які майже відповідні штатним шинами «Michelin».

2. Пневматична шина 550/75R21 моделі Бел-66А [3], радіальної конструкції 3 протектором підвищеної прохідності виробництва компанії «Белшина» (Республіка Білорусь). Індекс навантаження 160/162/164 (4000/4750/5000кг), індекс швидкості - J/G/F (100/90/80 км/год). Експлуатується у складі автомобілів «КрАЗ» різних модифікацій та вантажних автомобілів «МАЗ-Богдан 6317».

Шина 550/75R21 моделі Бел-66А має достатні показники керованості, гальмівних властивостей та інтенсивності зносу протектора.

Недоліком експлуатації автомобільних шин Бел-66А $€$ недостатня прохідність автомобіля в умовах бездоріжжя на чорноземних та глинистих ґрунтах Донецької та Луганської областей та в зимових умовах. В зв'язку з чим, слід зауважити, що малюнок протектора даної шини $\epsilon$ скоріше універсальним, а ознакою протектора підвищеної прохідності $€$ лише наявність бічних грунтозачепів.

Крім того, під час експлуатації автомобільної шини Бел-66А, спостерігаються випадки радіального розтріскування бокової частини шини при пробігах 20-25 тис. км (мал. 2).
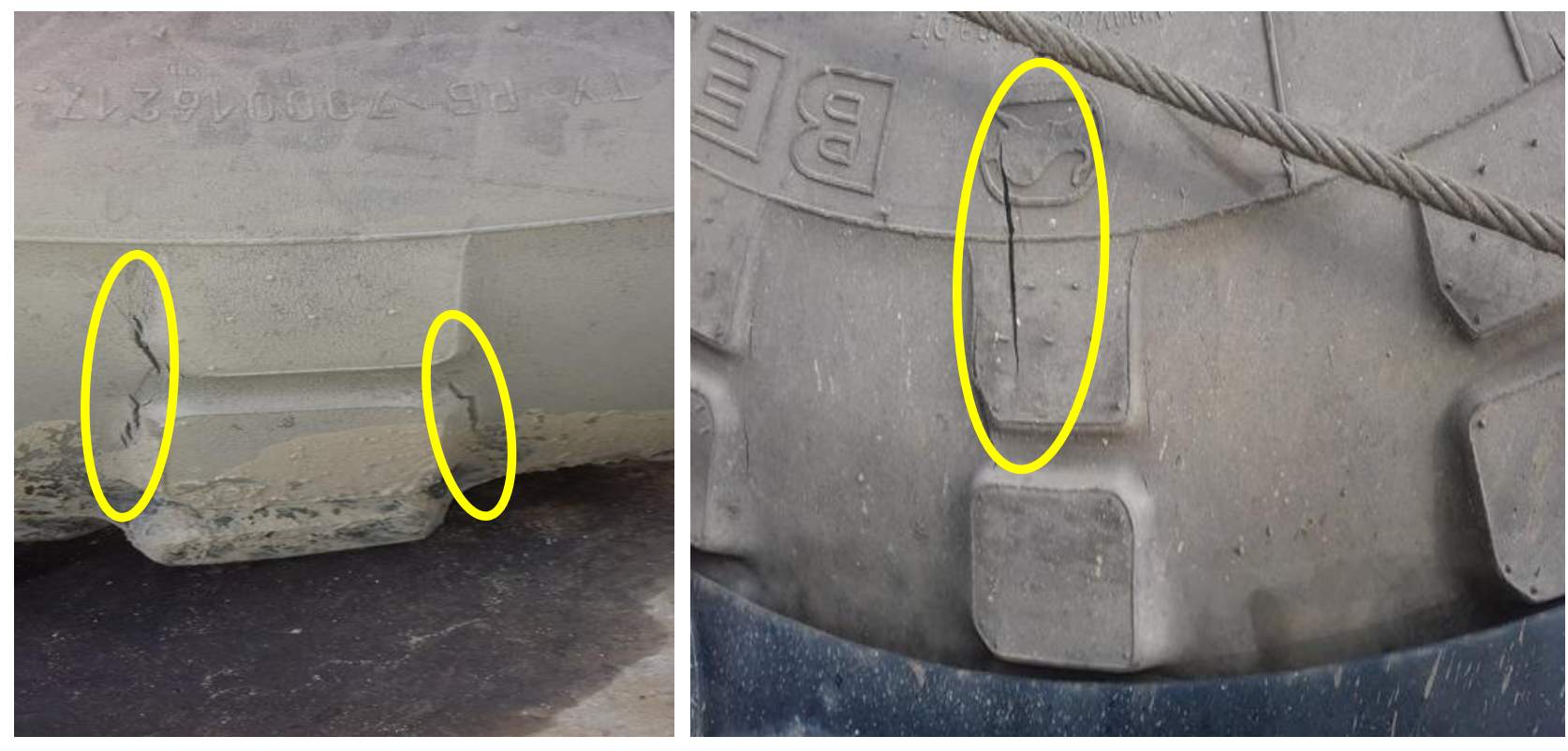

Мал. 2. - Розтріскування пневматичної шини Бел-66А при експлуатації у складі сідельного тягача «КрАЗ 6446»

3. Шина 550/75R21 моделі ИД-370 радіальної конструкції 3 протектором підвищеної прохідності, Індекс навантаження 160 (до 4500 кг), індекс швидкості - G (до 90 км/год). Експлуатується у складі автомобілів «КрАЗ» різних модифікацій [4].

Шина 400/85-21 моделі ИП-184 радіальної конструкції 3 протектором підвищеної прохідності. Індекс навантаження - 142 (до
2650 кг), індекс швидкості - G (до 90 км/год). Експлуатується в складі автомобілів «КамАЗ 4310».

Шини ИД-370 та ИП-184 виготовляються ПрАТ «Росава» для корпорації «УкрТехПром». Вказані шини під час експлуатації зарекомендували себе з позитивної сторони. Мають достатні показники керованості, прохідності та гальмівних властивостей. 
Разом з тим, зафіксовані випадки шин ИД-370, після 3-х, 4-х місяців експлуатації у радіального розтріскування бокової поверхні складі сідельного тягача «КрАЗ 6446» (мал. 3).

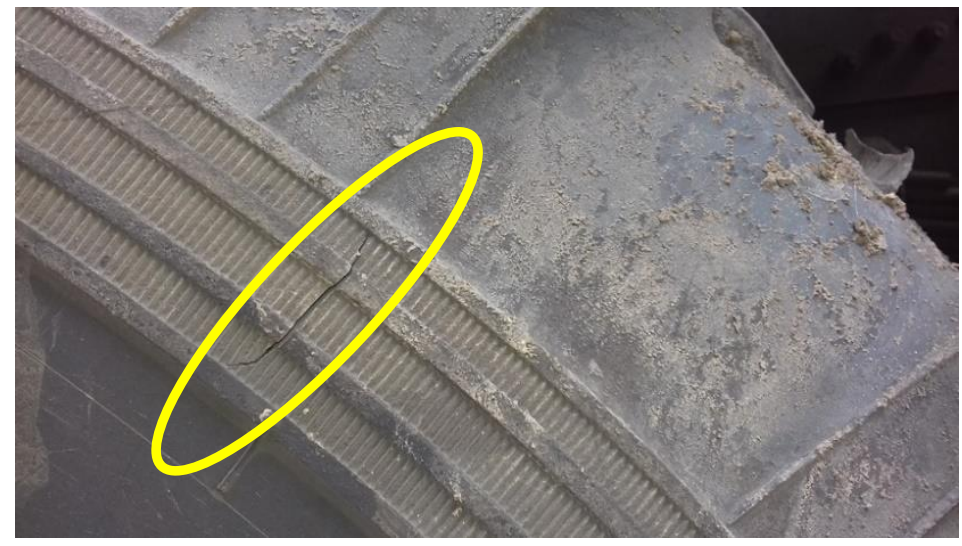

Мал. 3. - Розтріскування бокової частини пневматичної шини ИД-370

4. Шина 10.00 R20 Бел-114 [3] радіальної конструкції 3 універсальним малюнком протектора, виробництва компанії «Белшина» (Республіка Білорусь). Індекс навантаження - 146/143 (3000/2725 кг), індекс швидкості - К (до 110 км/год).

Шина 10.00 R20 Кама И-281 У-4 радіальної конструкції 3 універсальним малюнком протектора, виробництва ПАТ «Татнефть» (РФ). Індекс навантаження - 146/143 (3000/2725 кг), індекс швидкості - Ј (до 100 км/год).

Шини Бел-114 та Кама И-281 У-4 експлуатуються у складі напівпричепа «ВАРЗНПВ 6009" та мають однакові показники вантажопідіймальності - 2725 кг, для здвоєного колеса. Для 16 коліс, вантажопідіймальність по шинах становить $43600 \mathrm{Kг}$, що 3 врахуванням маси напівпричепа, $\epsilon$ недостатнім для транспортуванні САУ і танків та призводить до підвищення інтенсивності зносу протектора (мал. 4).

Крім того, на підвищення інтенсивності зносу впливають конструктивні особливості напівпричепа (наявність бічного ковзання коліс при поворотах, нерівномірність гальмівних зусиль на колісних парах).

Таким чином, наведена сукупність негативних факторів призводить до зниження ресурсу пневматичних шин у складі напівпричепа «ВАР3-НПВ 6009» на 30-60\%.

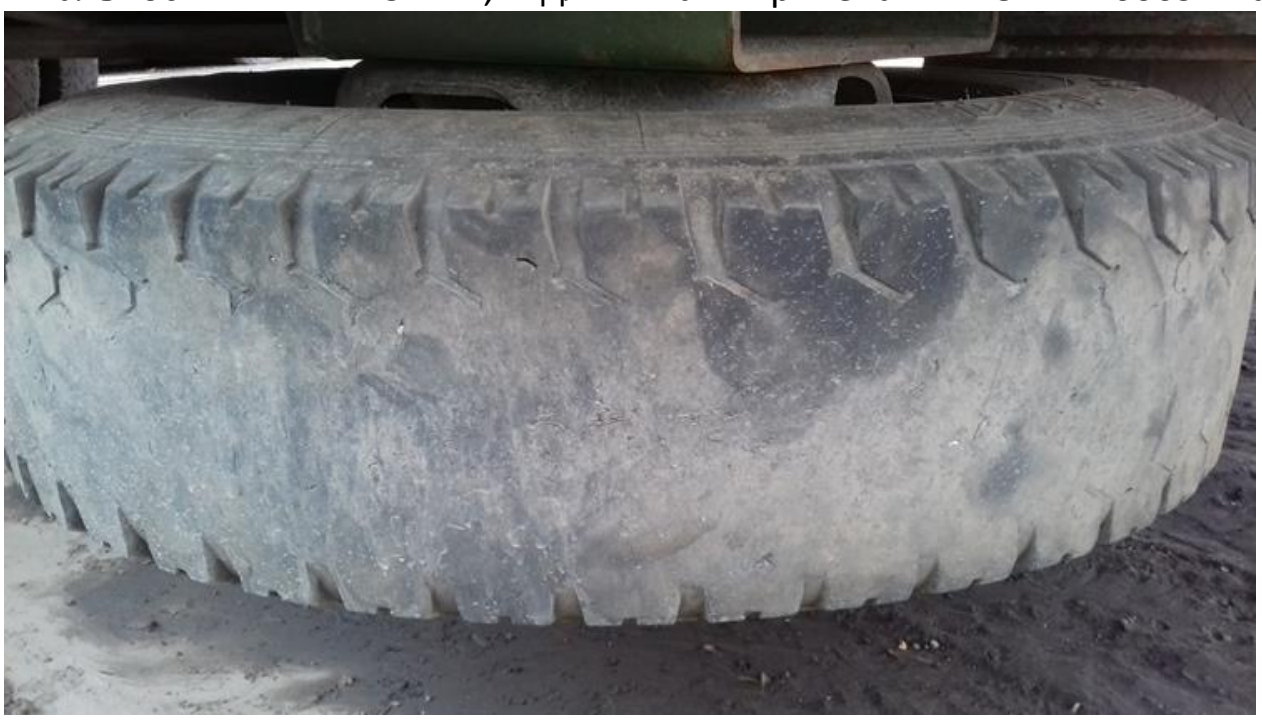

Мал. 4. - Протектор шини Бел-114 після 15000 км пробігу у складі напівпричепа «ВАР3-НПВ 6009» 
5. Шина 14.00 R20 Austone AT201 радіальної конструкції 3 універсальним малюнком протектора, виробництва КНР. Індекс навантаження - 164/161 (до 5000/4625 кг), індекс швидкості - G (до 90 км/год) [5].

Шина 14.00 R20 Austone AT201 експлуатується у складі напівпричепа «КВСЗ5001». Показник вантажопідіймальності для здвоєного колеса становить 4625 кг. Для 12 коліс, вантажопідіймальність по шинах становить - 55500 кг, що на 11900 кг більше в порівнянні з аналогічним показником для напівпричепа «ВАРЗ-НПВ 6009». В зв'язку 3 цим, ресурс шин у складі напівпричепа «КВС3-5001» вищий. На мал. 5 зображено протектор шини Austone AT201 з пробігом близько 50 тис. км. Крім того, маркування шини містить позначення «Regroovable», відповідно до якого конструкція шини передбачає можливість поглиблення малюнка протектора методом нарізування.

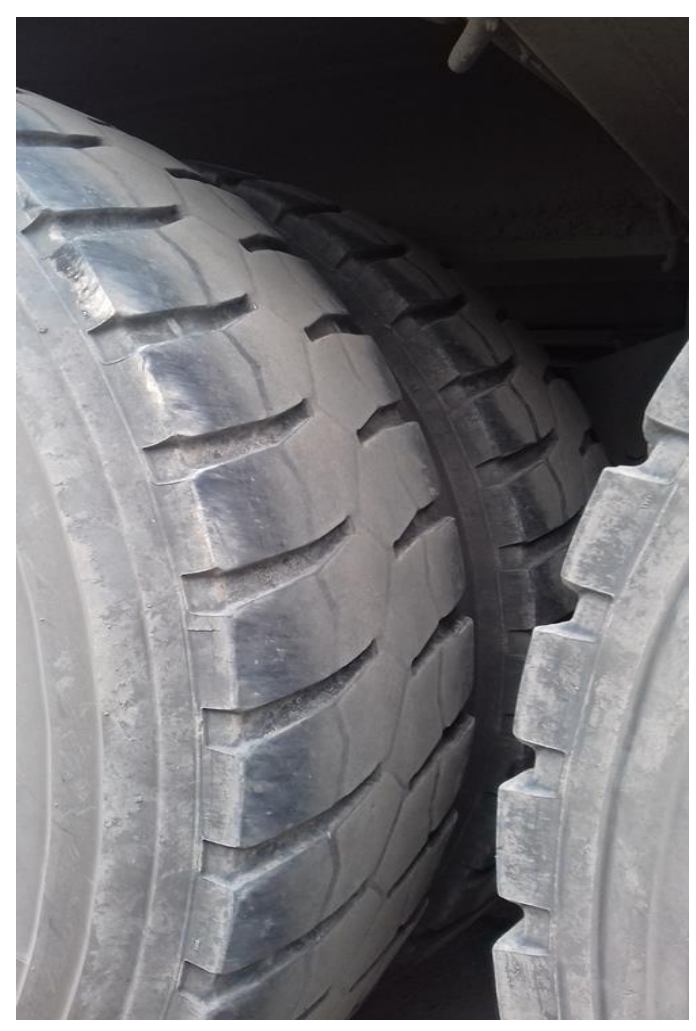

Мал. 5. - Пневматична шина Austone AT201, KHP

В цілому шина 14.00 R20 Austone AT201 у складі напівпричепа «КВС3-5001» зарекомендувала себе з позитивної сторони.

6. Шина 18.00-24 E-2 AOTAI [6] та шина 18.00-24 E-2 ARMFORCE [7], діагональної конструкції, вантажопідіймальністю 8200 кг, 3 малюнком протектора підвищеної прохідності. Експлуатуються у складі сідельних тягачів «МАЗ-537».
Основним недоліком пневматичних шин 18.00-24 E-2 AOTAI та ARMFORCE $\epsilon$ занадто м'яка гумова суміш i, як наслідок, висока інтенсивність зношування протектора на дорогах з поліпшеним покриттям особливо шини 18.00-24 E-2 ARMFORCE (мал. 6) та низька стійкість до механічних пошкоджень (мал. 7). 

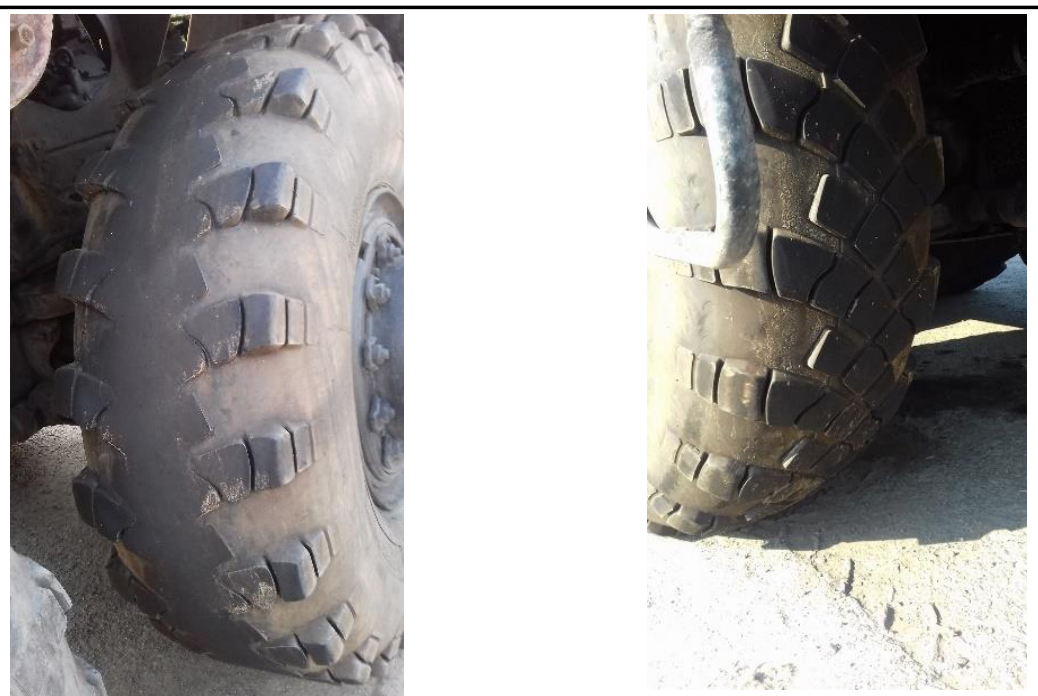

Мал. 6. - Протектор шини 18.00-24 E2 AOTAI (справа) та 18.00-24 E2 ARMFORCE (зліва) після пробігу близько 10000 км
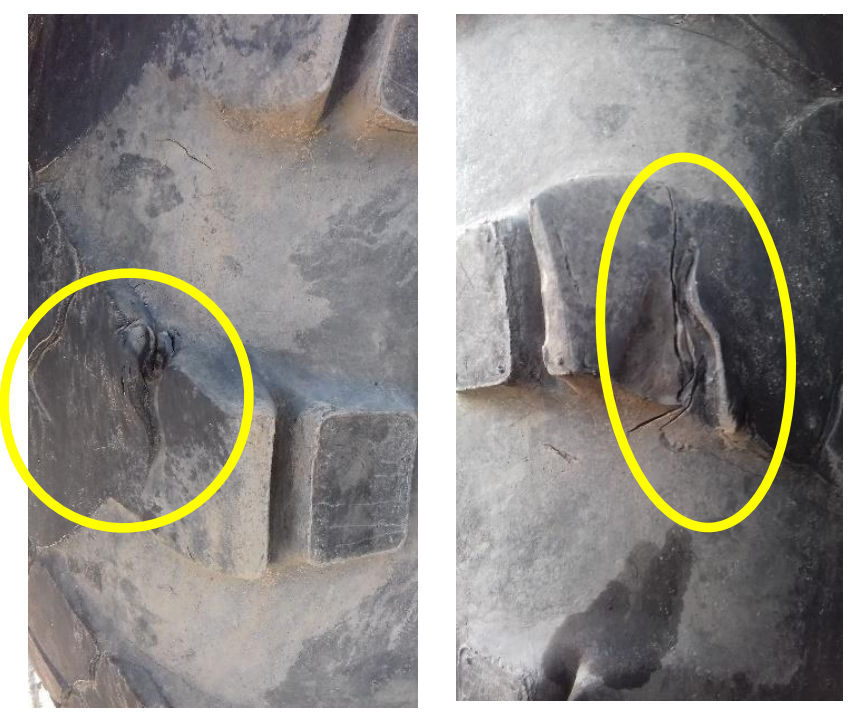

Мал. 7. - Типові механічні пошкодження пневматичних Шин 18.00-24 E-2 AOTAl та 18.00-24 E-2 ARMFORCE

7. Шина 320-457 (12.00-18) ARMFORCE [7], з протектором підвищеної прохідності, яка за своїм зовнішнім виглядом повторює шину К-
70, виробництва КНР. Експлуатується у складі вантажних автомобілів «ГАЗ-66» та його модифікацій (мал. 8).

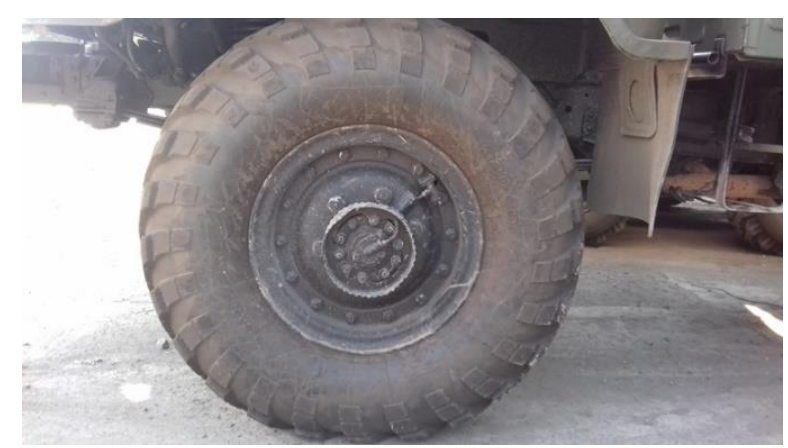

Мал. 8. - Пневматична шина 320-457 (12.00-18) ARMFORCE 
Основним недоліком пневматичної шини ARMFORCE 320-457 (12.00-18) є занадто м'яка гумова суміш i, як наслідок, висока інтенсивність зношування протектора на дорогах з поліпшеним покриттям. Крім того, висота малюнка протектора по центру шини на 4-6 мм менша від протектора шини К-70, що також зменшує ресурс.

Крім того, пневматична шина 320-457 (12.00-18) ARMFORCE не має будь-яких позначень (маркувань) окрім виробника, розміру та кількості шарів. Не вказана інформація щодо індексів навантаження, швидкості, максимального тиску, дати виготовлення та ін., що не відповідає вимогам ДСТУ 4406:2005 «Шини пневматичні. Загальні технічні вимоги безпеки» та може вказувати на відсутність сертифікації даної шини згідно Правил Європейської Економічної Комісії (ЄЕК) ООН №54 (для вантажних шин).

8. Шина BF Goodrich Mud-Terrain T/A LT 225/75R16 всесезонна, 3 протектором підвищеної прохідності, виробництва США, експлуатується складі санітарного автомобіля
«Богдан 2251» та спеціального автомобіля «Богдан 2351». Індекс навантаження - 110 (до 1060 кг), індекс швидкості - Q (до 160 км/год) [8].

Шина має достатні показники прохідності, керованості та гальмівних властивостей. Дана модель шини виготовлена з м'якої гумової суміші та призначена для позашляховиків. Режим експлуатації рекомендований компанією "Goodrich» для шини Mud-Terrain T/A LT складає: 80\% ґрунтові дороги та бездоріжжя і $20 \%$ - дороги з твердим покриттям. Разом з тим, в районі операції об'єднаних сил, автомобілі «Богдан 2251» та «Богдан 2351» інтенсивно експлуатуються по дорогах 3 твердим покриттям, що призводить до підвищеного зносу протектора шини та негативного впливу на елементи підвіски автомобіля.

Крім того, м'яка гума $€$ вразливою навіть до незначних механічних ушкоджень, що в сукупності з неоднорідністю конструкції, призводить до відшарування верхнього (покривного) шару бокової частини шини (мал. 9).

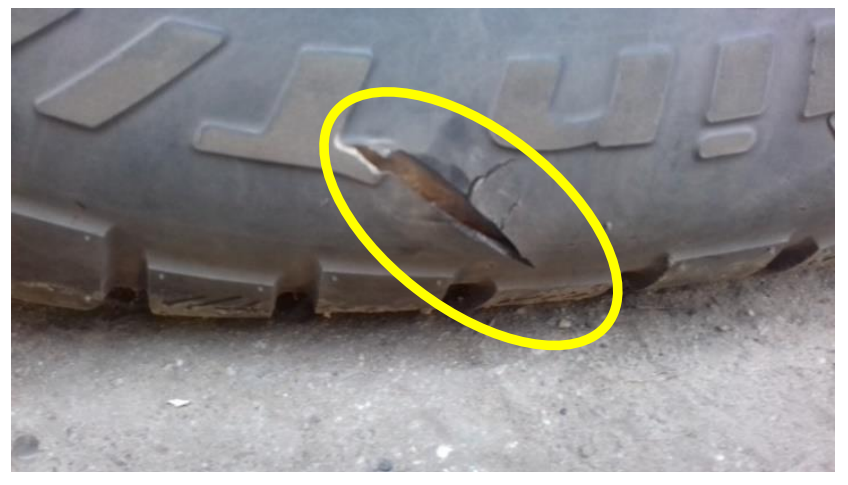

Мал. 9. - Механічне ушкодження бокової частини шини BF Goodrich Mud-Terrain T/A LT 225/75R16.

8. Шина Good Year Wrangler MT $37 \times 12,5 R 16,5$, всесезонна 3 протектором підвищеної прохідності та додатковою опорою (вставкою) Hutchinson VFI 16,5×8,5 [9], виробництва США. Індекс навантаження 133 (до 2060 кг), індекс швидкості - N (до 140 км/год). Експлуатуються у складі автомобілів HMMWV.

Шини Lakesea X Ranger 37×12,5R16,5 LT та
Brasa X Ranger 37×12,5R16,5 всесезонні 3 протектором підвищеної прохідності, виробництва КНР. Індекс навантаження - 133 (до 2060 кг), індекс швидкості - N (до 140 км/год). Експлуатуються у складі автомобілів HMMWV на замість шини Good Year Wrangler MT 37×12,5R16,5.

Вказані моделі пневматичних шин призначені для експлуатації на ґрунтових 
дорогах та бездоріжжі. Однак, в районі операції об'єднаних сил, автомобілі HMMWV інтенсивно експлуатуються по дорогах 3 твердим покриттям, що призводить до підвищеного зносу протектора шин. Крім того, досвід експлуатації шин Lakesea X Ranger $37 \times 12,5 R 16,5$ LT та Brasa $X$ Ranger $37 \times 12,5 R 16,5$ у складі автомобілів HMMWV показує, що зазначені шини мають гірші показники зносостійкості та стійкості до механічних ушкоджень ніж «штатна» шина Good Year Wrangler MT 37×12,5R16,5.

При цьому, під час заміни, в більшості випадків, «штатна» шина демонтується разом з додатковою опорою (мал. 10), що позбавляє автомобіль можливості продовжувати рух за відсутності надлишкового тиску повітря в шині.

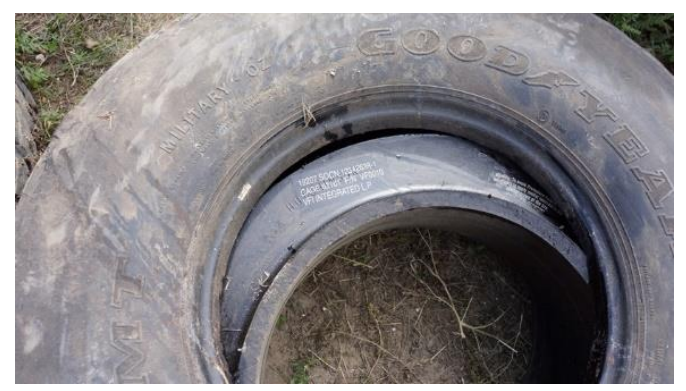

Мал. 10. - Пневматична шина Good Year Wrangler MT 37×12,5R16,5 з опорою (вставкою) Hutchinson VFI 16,5×8,5

\section{Висновки}

Аналіз практичного досвіду експлуатації показує, що переважна більшість пневматичних шин, які використовуються у складі БКМ та ВАТ за своїми характеристиками не відповідають реальним умовам експлуатації. Головними недоліками є:

висока інтенсивність зносу протектора;

низька стійкість до механічних ушкоджень;

схильність до руйнування елементів шини (розтріскування бокової частини та протектора, відрив грунтозачепів, тощо);

відсутність встановлених позначень (маркувань).

Причинами такої невідповідності $\epsilon$ :

заміна пневматичних шин передбачених розробником (виробником) зразків БКМ та ВАТ на шини інших моделей та/або виробників, які за своїми характеристиками поступаються «штатним». Така заміна $є$ вимушеною у зв'язку з високою вартістю (неможливістю закупівлі) оригінальних шин та/або відсутністю вітчизняних аналогів («БТР-4Е», «МАЗ-537», «ГАЗ-66», HMMWV, «Saxon»);

конструктивні (технічні) особливості зразків БКМ та ВАТ; перевищення максимально допустимої вантажопідіймальності шини («БТР-4Е», «ВАРЗНПВ 6009»);

наявність бічного ковзання коліс В поворотах, нерівномірність гальмівних зусиль на колісних парах («ВАР3-НПВ 6009»);

експлуатація ВАТ в дорожніх умовах, які не відповідають призначенню пневматичної шини («Богдан 2251», «Богдан 2351», HMMWV);

відсутність інформації щодо можливості та встановлених (рекомендованих) режимів експлуатації пневматичних шин зі зниженим тиском повітря (Бел-66А, ИД-370, ИП-184);

незадовільна якість пневматичних шин (18.00-24 E-2 AOTAI, 18.00-24 E-2 ARMFORCE, 320-457 (12.00-18) ARMFORCE)

відсутність маркування згідно Правил Європейської Економічної Комісії (ЄЕК) ООН (320-457 (12.00-18) ARMFORCE).

Крім того, не слід виключати такі чинники, як незадовільний технічний стан БКМ та ВАТ (негерметичність шинних кранів «БТР-4Е»), порушення встановлених режимів експлуатації БКМ та ВАТ та/або пневматичних шин. 
При цьому, діючі норми напрацювання пневматичних шин встановлені без урахування практичного досвіду їх експлуатації та, зазвичай, $є$ більшими від їх реального ресурсу. Такий стан справ унеможливлює процедуру списання та змушує експлуатувати пневматичні шини, які за своїм віком та (або) технічним станом не можуть встановлюватись на колісні транспортні засоби з міркувань безпеки.

Пропозиції (висновки). За результатами аналізу експлуатації пневматичних шин пропонується:
При постачанні пневматичних шин для потреб зС України:

обирати моделі (виробників), які сертифіковані за стандартами UN/ECE та відповідають вимогам ДСТУ 4406:2005;

проводити їх експлуатаційні випробування для визначення відповідності реальним умовам експлуатації та встановлення норм напрацювання (за Програмою і Методиками розробленими ЦНДІ ОВТ ЗС України);

сприяти розвитку виробництва
пневматичних шин великої вантажопідіймальності в Україні.

\title{
Список використаних джерел
}

1. Шина пневматическая $12.00 \mathrm{R} 20$ модели КИ113140 НС10 с распорным кольцом. Технические условия: ТУ У 25.1-30253385026:2013 / ПАТ «Росава». - Київ, 2013;

2. Шина пневматическая 12.00R20 модели КИ113 135K HС8. Технические условия: ТУ У 25.1-30253385-026:2013 / ПАТ «Росава». Київ, 2014;

3. URL: https://belshina.ua/gruzovyky/shina-bel66a-bez-o-I-525-70r21 (дата звернення 22.11.2019);

4. URL: https://utp.com.ua/catalog/gruzovyeshiny/?set_filter=Y\&arrFilter_392_303046410
7=Y\&PAGEN_1=2
(дата
звернення
22.11.2019);

5. URL: http://www.austonetire.com/productsview.aspx?id= 127 (дата звернення 22.11.2019);

6. URL: https://wap.china.cn/Truck-Tire/140014 184.html (дата звернення 22.11.2019);

7. URL: http://armforcerubber.com/MILITARYTIRE. html (дата звернення 22.11.2019);

8. URL: https://www.bfgoodrichtires.com/home (дата звернення 22.11.2019);

9. URL: https://www.hutchinson.com/en/ products/variable-function-insert-vfi-0 (дата звернення 22.11.2019).

\section{Анализ эксплуатации пневматических шин в зоне боевых действий}

\author{
Александр Почечун ${ }^{\text {; }}$; Николай Дорофеев ${ }^{B}$; Роман Фомин ${ }^{\mathrm{C}}$ \\ А Центральный научно-исследовательский институт вооружения и военной техники \\ Вооруженных Сил Украины, старший научный сотрудник, e-mail: gjxtxey1974@gmail.com \\ в Центральный научно-исследовательский институт вооружения и военной техники \\ Вооруженных Сил Украины, адъюнкт, e-mail: dorofeev83@теta.ua \\ с Центральный научно-исследовательский институт вооружения и военной техники \\ Вооруженных Сил Украины, старший научный сотрудник, e-mail: roman7803@ukr.net
}

\begin{abstract}
Аннотация
В данной статье проведен анализ эксплуатации пневматических шин в составе образцов боевых колесных машин и военной автомобильной техники, привлеченных к проведению операции на востоке страны. Указанные основные проблемы $и$ представлены предложения по их решению.
\end{abstract}

Ключевые слова: пневматическая шина, боевая колесная машина, военная автомобильная техника. 


\title{
Analysis of the operation of pneumatic tires in the war zone
}

\author{
Alexander Pochechun A; Nikolai Dorofeev ${ }^{\text {B; }}$ Roman Fomin C \\ ${ }^{A}$ Central Research Institute of weapons and military equipment of the Armed Forces of Ukraine, \\ Senior Researcher, Research Department for the Development of Arms and Equipment of Armored, \\ Mechanized and High-Mobility Forces; \\ ${ }^{B}$ Central Research Institute of weapons and military equipment of the Armed Forces of Ukraine, \\ post-graduation student; \\ c Central Research Institute of weapons and military equipment of the Armed Forces of Ukraine, \\ Senior Researcher, Research Department for the Development of Arms and Equipment of Armored, \\ Mechanized and High-Mobility Forces
}

\begin{abstract}
This article analyzes the operation of pneumatic tires as part of combat wheeled vehicles and military automotive equipment involved in the operation in the east of the country. The indicated main problems and suggestions for their solution are presented.

Currently, in the Armed Forces of Ukraine the issue of providing combat wheeled vehicles (CWV) and military automotive equipment (MAE) with pneumatic tires remains unresolved. The absence in Ukraine of its own production of heavy-duty pneumatic tires (over $2500 \mathrm{~kg}$ ), including adjustable pressure, forces us to operate foreign-made pneumatic tires (Republic of Belarus, China, and the Russian Federation). Many of them belong to the so-called "inexpensive" segment with mediocre quality and low wear resistance (especially the production of China) and is supplied by intermediaries without proper technical documentation. As a result, these pneumatic tires wear out during intensive use and must be decommissioned much earlier than the established production standards.

This article is based on practical work to study the experience of operating pneumatic tires as part of the CWV and MAE samples in the area of the operation in the east of the country.

The purpose of this article is to develop a system of views on improving the efficiency of combat wheeled vehicles and military automotive equipment using modern developments in the field of science and the appropriate technical level, will be useful in developing tactical and technical requirements for modern and promising weapons systems. The relevance of this issue for the Armed Forces of Ukraine has recently increased significantly, given the conduct of hostilities.
\end{abstract}

Keywords: pneumatic tire, combat vehicle, military vehicles.

\section{References}

1. Shyna pnevmatycheskaya $12.00 \mathrm{R} 20$ modely KY113140 NS10 s raspornym kol'tsom. Tekhnycheskye uslovyya: TU U 25.1-30253385026:2013 / PAT «Rosava». - Kyiv, 2013;

2. Shyna pnevmatycheskaya $12.00 R 20$ modely KY113 135K NS8. Tekhnycheskye uslovyya: TU U 25.1-30253385-026:2013 / PAT «Rosava». Kyiv, 2014;

3. Elektronnyy resurs: https://belshina.ua/ gruzovyky/shina-bel-66a-bez-o-l-525-70r21 (data zvernennya 22.11.2019);

4. Elektronnyy resurs: https://utp.com.ua/ catalog/gruzovye-shiny/?set_filter

=Y\&arrFilter_392_3030464107=Y\&PAGEN_1= 2 (data zvernennya 22.11.2019);
5. Elektronnyy resurs: http://www.austonetire. com/products-view.aspx?id= 127 (data zvernennya 22.11.2019);

6. Elektronnyy resurs: https://wap.china.cn/ Truck-Tire/140014184.html (data zvernennya 22.11.2019);

7. Elektronnyy resurs: http://armforcerubber. com/MILITARY-TIRE.html (data zvernennya 22.11.2019);

8. Elektronnyy resurs: https://www.bfgoodrichtires.com/home (data zvernennya 22.11.2019);

9. Elektronnyy resurs: https://www.hutchinson. com/en/products/variable-function-insert-vfi0 (data zvernennya 22.11.2019). 